\title{
Uma reflexão sobre a temporalidade no Parmênides de Platão
}

\author{
A reflection on the temporality in Plato's "Parmenides"
}

\section{Gérson Pereira Filho}

Resumo: A passagem 140e-141d do diálogo Parmênides nos remete a uma das conseqüências lógicas em relação ao "um", isto é, estar fora do tempo, como parte da demonstração argumentativa do filósofo eleata ao admitir a primeira hipótese de que "o um é" e as conseqüências disso para si mesmo. Aceitar a existência do "um" implica, segundo o método de análise utilizado por Parmênides, verificar cada uma das hipóteses possíveis nesses casos, em relação às suas predicações, para si e para outras coisas. Igualmente, o mesmo exercício deve ser feito se a hipótese for oposta, "se o um não é". Como podemos identificar na estrutura do diálogo nesta parte, duas hipóteses são levantadas em que "o um é" e suas nove consequências; no primeiro movimento (137c-142a), as possíveis predicações para este são negadas, e no segundo movimento (142b-155e) tais predicações e seus desdobramentos são reconhecidos. E a partir desse posicionamento que desenvolvemos nossa análise sobre a questão da temporalidade presente no diálogo e suas implicações mețodológicas e teóricas. Palavras-chave: Diálogo Platônico; Temporalidade; Tempo; Parmênides

Abstract: The passage 140e-141d of the Parmenides dialogue refers us to one of the logical consequences in relation to the "one", that is, to be out of time, as part of the argumentative demonstration of the Eleatic philosopher by admitting the first hypothesis that "the one is" and the consequences of this to the one itself. Accepting the existence of the one implies, according to the method of analysis used by Parmenides, to check each of the possible hypotheses in these cases, in relation to their predications, for themselves and other things. Equally, the same exercise should be done if the hypothesis is the opposite, "if the one is not." As we can identify in the structure of the dialogue in this part, two hypotheses are raised in which "the one is" and nine consequences thereof arise; in the first movement (137c-142a), the possible predications for this one are denied, and in the second movement $(142 \mathrm{~b}-155 \mathrm{e})$ such predications and their unfolding are recognized. It is from such placement that we develop our analysis on the issue of temporality addressed in the dialogue and its methodological and theoretical implications.

Keywords: Platonic Dialogue; Temporality; Time; Parmenides

\section{Introdução}

A passagem do diálogo Parmênides ${ }^{1}$ referenciada no título deste trabalho, passos 140e - 141d, nos remete a uma das consequências lógicas em relação ao "um”, qual seja, estar fora do tempo, como parte da demonstração argumentativa do filósofo eleata ao se admitir a primeira hipótese de que "o um é", e as consequências disto para si mesmo. Aceitar a existência do um, implica, segundo o método de análise utilizado por Parmênides, verificar cada uma das hipóteses possíveis neste caso, em relação a suas predicações, para si próprio e perante as outras coisas. Igualmente, o mesmo exercício deve ser feito se a hipótese for o contrário, "se o um não é".

\footnotetext{
${ }^{1}$ Seguimos como principal referência a seguinte edição bilíngue do Parmênides: texto estabelecido e anotado por John Burnet, com tradução, apresentação e notas de Maura Iglésias e Fernando Rodrigues. Recorremos também a outras edições disponíveis que, quando relevante, serão indicadas.
}

\footnotetext{
${ }^{\text {I }}$ Professor de Filosofia na Pontifícia Universidade Católica de Minas Gerais, Poço de Caldas, MG. E-mail: gerson@pucpcaldas.br. Orcid-ID: https://orcid.org/oooo-00o1-5838-202X
} 
Como podemos identificar na estrutura do diálogo, nesta parte são levantadas duas hipóteses em que "o um é”, e nove consequências daí decorrentes. No primeiro movimento (137c - 142a), são negadas as possíveis predicações para este um, e no segundo movimento (142b - 155e) se reconhece tais predicações e seus desdobramentos.

É a partir de tal colocação que desenvolvemos nossa análise sobre a questão da temporalidade presente no diálogo e suas implicações metodológicas e teóricas.

Nas duas primeiras hipóteses - "se o um é", as consequências, são:

1. Se é ou não, um todo ou partes;

2. Se possui ou não uma figura ou forma definida (reta ou circular);

3. Se está ou não no espaço;

4. Se está ou não em repouso e em movimento;

5. $\quad$ Se é diferente ou igual a si e a outro;

6. $\quad$ Se é semelhante ou dessemelhante;

7. $\quad$ Se é igual ou desigual;

8. Se está ou não está no tempo;

9. Se é ou não cognoscível.

Ocorre ainda, a terceira hipótese, em que "o um é e não é", o que implica estar em mudança contínua, e as consequências disto (155e até $157 \mathrm{~b}$ ); e a quarta e a quinta hipóteses em que "o um é" e as consequências disto para as outras coisas (157b até 16ob). Para as sexta, sétima, oitava e nona hipóteses parte-se do princípio de que “o um não é” e suas consequências possíveis (16ob até 166b).

A conclusão (166c), brevíssima e, na verdade, “inconclusiva”, não apresenta argumentos em apologia a nenhuma das hipóteses e seus desdobramentos. Ao contrário, retoricamente, apenas se conclui que não faz diferença que o um seja ou que o um não seja, que em qualquer dos casos são e não são, parecem e não parecem ser. Mais do que uma aporia, temos uma saída embaraçosa e obscura que muito se distancia da expectativa gerada na primeira parte do diálogo. Lá se travam entre Sócrates e Zenão as primeiras conversas que parecerão conduzir à exposição e defesa da ontologia parmenideana, suas concepções sobre a unidade, imutabilidade, não movimento do Ser; a não existência do Não-Ser; ou ainda, a sinalização de que encontraríamos a contestação precisa de Sócrates a Zenão e seu mestre, com base na indefinida existência das Ideias em si, e os modos de participação sensível, nas mesmas. Mas não são tais esclarecimentos que vamos encontrar no desenvolvimento dialógico.

Como indica o próprio texto, a questão da existência ou não do um, é um exemplo casual, utilizado diante do contexto anterior da discussão, onde Sócrates e Zenão trataram da unidade e da multiplicidade das coisas. Poderia ter sido utilizado outro exemplo qualquer, pois o que pretende Parmênides no desenvolvimento do diálogo não parece ser demonstrar a tese ontológica da existência ou não do um, o que, por sua vez, nos conduziria à especulação sobre ser o um (unidade) a própria identidade do ser parmenideano, ou um atributo deste. A intenção de Parmênides nos parece ser menos ontológica (ao menos nesta parte do diálogo) e mais metodológica, na intenção de demonstrar a Sócrates como deve ser a investigação lógico-racional de uma tese para possibilitar sua argumentação.

Nesta parte do ambiente cênico desenvolvido na obra, Parmênides foi requisitado por Sócrates, com o apoio de Zenão e dos demais presentes (Pitodoro, Aristóteles e talvez mais alguém) neste antológico, embora, talvez fictício encontro (como acham a maior parte dos comentadores, embora outros apontem uma citação no diálogo Teeteto (183e), em que Sócrates se refere ao suposto encontro). O interlocutor direto do diálogo deixa de ser Sócrates, substituído por um jovem Aristóteles (provavelmente em referência a um futuro tirano ateniense, aqui personagem; e, não, obviamente, ao filósofo peripatético). Sócrates se 
coloca na posição de ouvinte. Parmênides exige que seu interlocutor seja o mais jovem de todos os presentes, razão pela qual se apresenta este jovem Aristóteles.

Há um jogo de idades que fica bastante explícito na composição dramática do diálogo platônico e parece não ser mero acaso ou estilo literário, pois permite algumas considerações que costumam ser levadas em conta por vários estudiosos e, no caso deste modesto trabalho, também ganha relevância, pois, afinal, diz respeito à algumas das divagações sobre a temporalidade que abordaremos.

O diálogo Parmênides, ainda que não seja dos mais extensos, tem sido apontado como um dos mais complexos, em toda a obra platônica, por adentrar no campo enigmático da metafísica e da epistemologia ontológica, desafiando pesquisadores e exegetas de todas as épocas, de modo especial como uma possível chave para se desvendar a obscuridade da “teoria das formas", para muitos, eixo central no pensamento socrático e platônico.

Entretanto, o diálogo apresenta diversos movimentos e, em sua maior parte, o intenso debate ontológico sobre a existência ou não das Formas e suas possibilidades enquanto Ser, se dilui e não se torna culminante no texto, que se desvia para outras vias, sobretudo a metodológica.

Vejamos que o início dramático do diálogo vem, como de costume noutras obras, marcado pelo preâmbulo que também não deve ser entendido meramente como um perfume estilístico, pois em geral estes preâmbulos são reveladores de profundas intenções e métodos no contexto dialógico. No caso do Parmênides, o preâmbulo (126a-127a), ao descrever a viagem proposital de Céfalo e seus companheiros de Clazômenas à Atenas, onde se encontram com os irmãos de Platão, Adimanto, Glauco e depois, com o meio irmão Antifonte, não torna explícito o porquê do interesse em ouvirem sobre o suposto encontro entre Sócrates, Zenão e Parmênides, que ocupa o cenário principal do diálogo. Seria uma mera curiosidade histórica e especulativa sobre a trajetória de Sócrates e as possíveis bases de desenvolvimento de seu pensamento? Haveria um interesse em compreender a fundo possíveis divergências ou convergências entre as teorias eleáticas e as socráticas? Haveria uma busca filosófica de fato, na tentativa de elucidar as dificuldades ontológicas da "Teoria das Formas" possivelmente elaborada por Sócrates? Ou seria um interesse metodológico, sugerido por Platão por meio dos personagens, direcionado a um plano de exposição da construção do método dialético como modelo de arguição filosófica?

Notemos que o argumento do procurado Antifonte (127a) que narraria o encontro entre os filósofos eleatas e os jovens atenienses, foi o mesmo apresentado por Parmênides quando instigado por Sócrates e Zenão a se pronunciar detalhadamente sobre suas posições (136d). Antifonte reluta inicialmente em narrar a história, alegando que "era muito trabalho" (127a: polý gar éphe érgon einai $)^{2}$. Ora, este Antifonte é descrito nessas poucas frases como alguém que durante bom tempo frequentou o circuito filosófico ateniense, mas que optou por mudar radicalmente de vida e atividades, recolhendo-se em uma morada afastada, ambiente rural, provavelmente, passando a maior parte do tempo a cuidar de cavalos. Tal descrição nos revela um personagem bastante exausto das elucubrações filosóficas, que busca desocupar sua mente numa atividade rude e natural. Coagido pelos visitantes, acabou por ceder e se dispôs a narrar a história que já contara por inúmeras vezes, e que o enfadava, assim como enfadonha se tornara a filosofia, para ele.

O ancião Parmênides, quando pressionado por Sócrates e pelo discípulo Zenão a discorrer sobre suas teses, também alega que "é muito trabalho... para alguém da minha idade (136d, polý érgon.).

${ }^{2}$ A tradução das citações segue a referência indicada na nota anterior. 
Em ambos os casos se trata de uma justificativa para o trabalhoso exercício mental e racional exigido pela filosofia na tarefa de construir teses de fato consistentes e convincentes. É a dureza do raciocínio lógico, da construção coerente da linguagem e da argumentação, enfim, o árduo trabalho dialético a que se deve dedicar quem de fato pretende praticar a filosofia e que pode, até mesmo, enfadar a seus praticantes.

É neste sentido que chamamos a atenção para o fato de que o intuito que prevalece no diálogo Parmênides seja talvez mais de ordem metodológica e lógica, do que propriamente ontológica ou metafísica. Parmênides parece então, estar tomado por este enfado, e se recusa a adentrar de imediato numa discussão densa em torno do Ser e seus atributos, sobretudo com interlocutores ainda tão jovens com pouco domínio sobre tais questões filosóficas de peso (Sócrates e o jovem Aristóteles). Sem tornar-se antipático, até porque ele era o visitante externo em Atenas, sutilmente desvia a conversa das questões ontológicas iniciais, transformando-as em exemplos, para aproveitar a entrevista num sentido pedagógico: ensinar aqueles jovens como devem exercitar seu raciocínio se pretendem seguir a vida filosófica.

O movimento do diálogo que se segue ao preâmbulo, a partir da narrativa de Antifonte (127e, até 137c) em torno das conversações entre Zenão e o jovem Sócrates, chega a sinalizar para um conteúdo onde iria, ao que parece, imperar questões ontológicas e metafísicas pertinentes ao debate sobre a "Teoria das Ideias" e alguns de seus desdobramentos, como a questão da multiplicidade, da unidade, do movimento, do repouso, da semelhança e dessemelhança dos seres, dos seres sensíveis e inteligíveis. Porém, a entrada de Parmênides no debate, vai aos poucos deslocando o rumo pretendido por Sócrates que insiste na busca de argumentações sobre as teses em si do Um e do Múltiplo; enquanto o mestre eleata se desvia para uma discussão aparentemente mais simples, que seria a questão do método de investigação racional e não exatamente o conteúdo ontológico, ao menos no contexto desta conversa.

\section{O diálogo Parmênides: metodologia mais que ontologia}

Zenão já havia advertido a Sócrates de que o principal objetivo na exposição feita em torno de alguns de seus escritos que tornara públicos naquela ocasião, teriam sido redigidos ainda em sua juventude com a finalidade de servirem como "uma assistência ao argumento de Parmênides contra os que tentam caricaturá-lo" (128c-d); disse Zenão a Sócrates que não levasse tão a sério as teses ali explicitadas, pois o principal seria entender o propósito dos escritos que teriam menor pretensão do que aquelas imaginadas pelo jovem interlocutor. Sócrates não teria compreendido o verdadeiro teor dos escritos de Zenão, mais preocupados em exercitar a demonstração de um argumento do que propriamente defender a verdade de uma tese ou princípio. Mais um exercício metodológico e lógico, do que ontológico.

É por aí que Parmênides prossegue (a partir de $137 \mathrm{c}-\mathrm{d}$ ), ao afastar-se de um aprofundamento nas questões que marcam a ontologia e a epistemologia, para reforçar aspectos do método de indagação e argumentação. Não que os temas levantados pelas hipóteses apresentadas não permitissem as abordagens epistêmico-ontológicas necessárias para o desenvolvimento das teses parmenideanas. No entanto, considerando o lugar dialógico do Parmênides no corpus platônico, especialmente ao se considerar os aspectos de suas várias temporalidades, como nos ensina a tese inovadora a este respeito, por Benoit $(2015)^{3}$, que tem servido de base para nossa leitura dos diálogos, naquele contexto, o

\footnotetext{
${ }^{3}$ Esta obra é um primeiro volume onde o autor nos apresenta uma introdução à sua densa e revolucionária tese sobre os equívocos interpretativos da obra platônica ao longo da tradição de comentadores, que teria feito com
} 
propósito foi outro; tratava-se de oferecer uma iniciação filosófica ao jovem Sócrates e a outros de seu círculo, apontando alguns indícios de conteúdos que passaram a integrar outros contextos dialógicos ao longo da obra platônica.

Conforme defende Benoit, a interpretação dos diálogos deve estar fundamentada no entrelaçamento das várias temporalidades que caracterizam o corpus a partir do contexto de elaboração da obra, o tempo do pensamento exposto, o tempo dramático e a temporalidade da léxis, ou seja, a ação do dizer dos personagens. Neste sentido é proposto um ordenamento dramático dos diálogos segundo o encadeamento de suas falas, acontecimentos, dados históricos etc., ao que Benoit chama de "diatáxis": "o Parmênides, no interior da diatáxis segundo a léxis, é o primeiro ou o mais antigo dos Diálogos. Esta afirmação é atestada de maneira indubitável por várias passagens"4.

Desta constatação podemos inferir que pela temporalidade dramática, o diálogo Parmênides seria o início da vida filosófica de Sócrates e seu círculo de convivência, contrapondo-se já à antiga tradição eleática. Isto trará outras consequências metodológicas, conceituais e hermenêuticas da obra platônica que não cabe discutir aqui. Apenas a título de complementação, o tempo dramático deste diálogo pode, então, ser situado por volta do ano 450 a.C. Deste modo será possível construir o ordenamento de todo o conjunto dos diálogos, até ao último deles, As Leis.

Quanto ao tempo de produção deste diálogo, o tempo da poiésis, como denomina Benoit, o Parmênides estaria dentre os escritos da fase mais tardia do autor Platão, como sugere a edição aqui utilizada: “[...] a estilometria ... muito cedo atribuiu ao 'Parmênides' um lugar incontestável no grupo dos diálogos da chamada fase média ou da maturidade [...] $]^{5}$.

Aqui cabe adiantar, por exemplo, a intencionalidade presente na cena dramática do diálogo Parmênides ao enfatizar a temporalidade cronológica da vida dos personagens. Não à toa tais idades são descritas com bastante detalhes (127b-c): Parmênides já bem idoso, com cerca de sessenta e cinco anos; Zenão perto dos quarenta; Sócrates bastante jovem, talvez menos de vinte; e o tal Aristóteles, apresentado como o mais jovem de todos no encontro (137c), talvez abaixo dos 18 anos. Também não pode ser desconsiderada a intenção do diálogo ao indicar com certa precisão as temporalidades dos acontecimentos descritos: a mais distante delas, a ocasião das "Grandes Panatenéias" que teriam trazido Zenão e Parmênides à Atenas, ao menos cinquenta anos antes do encontro entre Céfalo e os compatriotas de Clazômenas e a narrativa de Antifonte. Por ora, cabe chamar a atenção para a preocupação do autor dos diálogos em situar os personagens a partir de suas diferenças em idades, um detalhe que poderia não fazer falta, não fosse a ênfase metodológica que se pretenda oferecer à obra. Parece-nos que ao trazer o ancião Parmênides até certo ponto já cansado de tantas exposições filosóficas, nem sempre bem compreendidas, que tenta se esquivar de uma discussão mais profunda, em companhia do amadurecido discípulo, Zenão, em sua "meia idade", que recorre, para entretenimento dos ouvintes a um texto de sua juventude, diante dos ansiosos jovenzinhos Sócrates e Aristóteles, impertinentes em suas

que se perca uma leitura de fato autêntica dentro daquilo que foi proposto pelos próprios diálogos. A proposta de Benoit é uma leitura dos diálogos platônicos a partir de uma metodologia que ele denomina das "temporalidades", ao se considerar como pressupostos fundamentais para a compreensão dos diálogos, o entrecruzamento entre as várias temporalidades ali presentes: a dramaticidade cênica e histórica, a gênesis, a léxis, a poiésis, a noêsis. Para uma compreensão detalhada da metodologia das temporalidades proposta por Hector Benoit, temos sua tese de livre-docência, defendida na Unicamp, em 2004: "Em busca da odisseia: a questão metodológica das temporalidades e a materialidade da lexis”. A tese resultou em duas obras indispensáveis àqueles que buscam novas maneiras de ler e compreender Platão: Platão e as temporalidades - a questão metodológica e A Odisseia de Platão - as aventuras e desventuras da dialética.

${ }^{4}$ BENOIT, Platão e as temporalidades, p. 125.

${ }^{5}$ IGLÉSIAS; RODRIGUES, Platão. Parmênides, p. 7. 
primeiras aventuras filosóficas, o diálogo nos passa mais a ideia de se tratar de uma demonstração do autor frente aos métodos e procedimentos a serem adotados no exercício filosófico do que uma preocupação em apresentar alguma doutrina desenvolvida.

O Parmênides do diálogo não parece disposto a se deter longamente em suas teses nesse momento; nem mesmo Zenão; sobretudo, ao perceberem que seus interlocutores ainda pouco revelam de domínio sobre as grandes questões que ocuparam esses pensadores até então, e que resultaram nas antagônicas teses dos eleatas frente aos pitagóricos, aos heracliteanos e aos físicos. Este diálogo apresenta um Parmênides já bastante idoso, impaciente com as ingênuas especulações juvenis, embora não agressivo. Ao contrário de se afastar ou tratar os jovens com desdém, Parmênides assume o papel de mestre, disposto a ensinar aos jovens aprendizes que seria necessário um aprendizado frente aos primeiros procedimentos do método filosófico ou dialético, antes de virem a se ocupar de conteúdos que exigirão muito trabalho do lógos e de percorrerem o difícil percurso da única via capaz de levar ao conhecimento, que é a razão, (como já havia sido dito no Poema).

Enquanto Sócrates insiste em discutir conceitualmente as teses que aparecem de modo diluído, fragmentado, tanto Zenão quanto Parmênides direcionam para a necessidade primeira: aprender o exercício do raciocínio filosófico e dialético, a argumentação e a demonstração do argumento de forma lógica, pois somente assim se poderá chegar a algum lugar.

Há um deslocamento de foco que deve ser levado em conta pelos pesquisadores. $\mathrm{O}$ Parmênides talvez ofereça menos elementos para se investigar a ontologia e, em particular, a ontologia das Formas-Ideias, do que outros diálogos platônicos; e é provável que ofereça mais indicativos para se pesquisar sobre a construção do método dialético como instrumento da filosofia, ainda que a dialética platônica acabará por se afastar do método parmenideano e também atravessará um longo percurso para se elaborar.

No entanto, ao se considerar a importância da temporalidade dramática na interrelação dos diálogos, faz sentido trazer à tona o debate ali travado, início do percurso do lógos dialético platônico por meio do personagem Sócrates, como se refere Parmênides (130e):

É que ainda és jovem, Sócrates, disse Parmênides, e a filosofia ainda não se apoderou de ti como, segundo minha opinião, ainda se apoderará, quando então nenhuma dessas coisas desprezarás. Por agora, ainda atentas para as opiniões dos homens, devido a tua idade ${ }^{6}$.

\section{O Um e o Tempo}

Embora nossas colocações preliminares tenham se ocupado de uma concepção geral em torno do diálogo Parmênides, ressaltando seu aspecto metodológico e didático, mais do que o ontológico e metafísico, pretendemos ainda, para cumprir o anunciado no título, refletir sobre a difícil questão do tempo como ali é colocada.

Na oitava consequência da primeira hipótese de que "o um é" (140e até 141d), parte-se do princípio de que para existir, o um deve estar fora do tempo, não participar nem estar em tempo algum (oúd éstin én tini kronoi). Assim, como não caberia ao um, nenhuma predicação, também não caberia a ele, estar no tempo. A participação do um, no tempo, significaria admitir contradições como a de ser, concomitantemente, mais velho, mais jovem ou da mesma idade que si ou de outra coisa. Se uma das características do um é ser o que é,

${ }^{6}$ IGLÉSIAS, RODRIGUES, Platão, Parmênides, p. 32. 
não poderia estar sujeito às mudanças impostas pelo tempo, que sempre torna uma coisa mais velha que outra ou que si, implicando também que algo se torne, então, mais jovem ou da mesma idade que outro algo. Ora, também não caberia ao um, tornar-se diferente ou dessemelhante ao que é, situações que ocorreriam, se estivesse sujeito ao tempo.

Entretanto, se considerarmos, como se faz na segunda hipótese, que o um está no tempo e dele participa (kronou metéxei), significa entender que, por estar o um ontologicamente vinculado ao ser, estar no tempo é característica do ser, que participa tanto do passado, quanto do futuro, quanto do agora. De modo igual à questão da medida, em que o um, assim como o ser, pode participar da grandeza e da pequenez, bem como em outros aparentes estados de contradição; há que se aceitar a possibilidade de participação simultânea nas três dimensões do tempo, passado-presente-futuro. Seja perante si mesmo ou perante outras coisas, a natureza do um, se participa do tempo, agrega a capacidade de ser mais velho, mais jovem e da mesma idade, simultaneamente, o que significa dizer que também, não é mais velho, nem mais jovem, nem da mesma idade. $\mathrm{O} u m$, portanto, é e não é; participa do tempo e não participa, está e não está sujeito à mudança.

Mas como se dá a mudança ou a não mudança? No tempo? A terceira hipótese diz que tal ocorre naquilo que se chama de "instante" (exaíphnes, 156d). Esse estranho elemento que não é passado, nem presente, nem futuro; não é repouso, nem movimento. É algo entre cada um deles. $\mathrm{O}$ instante é a passagem que indica a mudança e a presença no tempo. Ser o que é como é, não implica necessariamente estar no tempo do agora; como ser o que se foi ou que virá a ser, passado e futuro, em si, não conota a condição de estar no tempo. É preciso perceber esse tênue movimento entre uma coisa e outra, o instante é o que representa o estar no tempo que passa. Tal hipótese nos aproxima das teses de Heráclito, de que só há a mudança, pois tudo flui e se transforma a cada instante; só há o instante da mudança; o tempo seria a mudança contínua; o passado não é, pois já passou; assim como futuro ainda não é; e o presente não permanece, tudo se resume ao instante, esta contínua transição.

Este termo aqui utilizado como instante (exaíphnes), recebe outras conotações similares, como nos aponta Puente ${ }^{7}$. Para o pesquisador, tal expressão é utilizada por Platão em outros diálogos num sentido trivial. Já no Parmênides o conceito adquire sentido substancial e coloca-se como um intermediário entre os polos; a metaxy entre o tempo e a eternidade, ou, nos baseando nas citações acima, este instante é o intermediário entre o passado-futuro que constitui o presente. $\mathrm{O}$ termo indicaria outros sinônimos, como "de repente", "repentinamente", "súbito", e se caracterizaria como um elemento próprio e não uma parte de um polo ou outro; ou seja, este exaíphnes seria não uma parte do passado e outra do futuro, não uma parte do tempo (que se move) e da eternidade (imóvel), mas um outro algo, e aí residiria a preocupação central do diálogo, captar este "de repente", este "súbito", este "instante".

Se tais atributos se aplicam ao um, também são válidos para as outras coisas, já que a unidade estabelece a relação. Assim será também para as coisas sensíveis como para as ideias das coisas.

Nas últimas quatro hipóteses apresentadas, se o um não é, obviamente, a não existência do um descarta qualquer atributo que se possa atribuir a ele. Nada é no um, se ele não existe. Consequentemente, não faz sentido pensar o tempo, nem qualquer outra relação, pois simplesmente o um não é, e nada é.

Como o texto final nada conclui do ponto de vista de qual seria a hipótese viável, não há como concluir, afinal, que concepção se tem do um e de seus predicados, incluso aí a

\footnotetext{
${ }^{7}$ PUENTE, Ensaios sobre o tempo na filosofia antiga.
} 
questão do tempo. Afinal, ficamos sem saber se o um participa ou não do tempo; pois, na verdade, ficamos sem saber se o um é ou não é. Mas a partir daí, abre-se uma nova questão: o que é o tempo nesta perspectiva ontológica? Pelas considerações apresentadas nas várias hipóteses, o tempo pode ser compreendido conceitualmente como unidade de medida (mais velho, mais jovem, a mesma idade); como estado de uma natureza em transformação, a passagem de uma coisa à outra; como unidade física, entre o repouso e o movimento.

Se levarmos em conta que o diálogo teria como tônica central a questão "das FormasIdeias” ou que seja, de fato, uma demonstração das teses ontológicas dos eleatas, caberia então verificar o tempo enquanto uma entidade metafísica ou uma realidade ontológica (a Forma-Ideia do tempo), e ainda uma verificação no contexto da filosofia antiga onde o tempo, por vezes nos é colocado como uma entidade mítica; e, se isto for possível, verificar em que grau o tempo e a temporalidade chegaram a ser pensados enquanto condição da historicidade humana e seus acontecimentos.

Tentaremos verificar de modo introdutório um pouco sobre a concepção do tempo em Parmênides (o filósofo, não o diálogo) e em Platão (a partir de algumas referências nos diálogos).

\section{Sobre o Tempo em Parmênides}

O poema de Parmênides $^{8}$ parece não apresentar nenhuma referência direta ao tempo. Entretanto, ao se conceber o ser e seus atributos, pode-se indicar alguma relação com a primeira hipótese do diálogo que vem sendo tratado, em sua oitava consequência, de que o um, se é, estaria fora do tempo (140e). Ou seja, em princípio, a investigação racional sobre o ser revelaria que este é não nascido e sem fim, "não foi nem será" (Fr. 8.3-4). O não-ser igualmente é não nascido e não terá fim, porém pela negatividade de sua existência e a impossibilidade de ser pensado pela via da razão. Ao ser, pode ser tributada a qualidade de não ter nascido e não ter fim, enquanto positividade, por existir para além do movimento e da mutabilidade; não ter princípio nem fim, estar livre da gênese e da destruição (Fr. 8, 25/27).

Ainda que indiretamente, a ideia de princípio e fim, gênese e destruição, são referências que podem nos indicar o tempo, como uma entidade ou um estado ontológico que escapa à natureza do ser, apreendido pela via da razão; somente a via da opinião permite a percepção dos seres efêmeros e aparentes que na multiplicidade estariam sujeitos aos estados do tempo.

Em seus comentários interpretativos ao Poema, Santos destaca que ali são apresentados alguns "sinais" ou atributos do ser, tais como se manifestar de modo indivisível, imóvel, indestrutível, sem princípio nem fim, portanto infinito, que está para além do espaço e do tempo, pois "o ser é um eterno presente uno, homogêneo e contínuo"9.

De acordo com Spinelli, para Parmênides, sendo a razão a única via capaz de inteligir e falar sobre o ser, a este se refere como o todo pleno, numa nova interpretação da physis, apresentando-a como esta unidade da Natureza, do Cosmos, como um ente único, contínuo, imóvel e uma série de características que se opõem às concepções físicas vigentes, voltadas para a percepção sensível da realidade natural. Para Parmênides,

O cosmos é eterno, então ele não teve um começo no tempo e, nem tampouco, terá um fim [...] Não tem passado e nem futuro, pois sendo

\footnotetext{
${ }^{8}$ Citações de fragmentos do Poema, de Parmênides, com base na tradução de José Trindade Santos.

${ }^{9}$ SANTOS, Parmênides, Da Natureza, p. 96.
} 
eterno, é sempre igual e presente. Ele não está submetido a um antes e um depois, de tal modo que, num período de tempo, é e depois não-é, por isso ele é em sentido absoluto, sem que possamos atribuir-lhe uma gênese ou como e de onde nasceu $[\ldots]^{10}$.

Nos fragmentos coletados por Kirk, Raven e Schofield, é feito o comentário de que os versos de Parmênides "têm por finalidade provar que o que é não pode nascer nem perecer" (verso 21), e que o ser "nunca foi nem será, pois é agora como um todo" (versos 5-6); ou seja, o ser desconhece o passado e o futuro, pois, "é uma existência num eterno presente"11. O tempo aqui seria identificado a um conceito cosmológico, atributo a que está sujeito aquilo que possui uma origem, uma trajetória existencial e um fim. O ser parmenideano, portanto, estaria, nesta concepção, fora do tempo.

Entretanto, o pesquisador norte-americano Richard Mckirahan interpreta de modo diferente, dizendo que não há no poema nada que confirme esta colocação de que o ser é atemporal. Para este autor, rejeitar o passado ou o futuro, significa dizer que o que é, o é agora, no presente; ainda que já tenha sido no passado, naquele momento se estaria sendo, no presente; igualmente, o vir a ser no futuro, não é, e quando o for, será presente. O ser não excluiria assim a temporalidade, mas a identificaria de modo contínuo como o tempo sempre presente. Sendo a intenção de Parmênides afirmar o que é e rejeitar o que não-é, o passado não é mais e o futuro ainda não é; resta o presente como a característica do que é. Portanto, neste caso, o ser não é atemporal, mas é sempre no tempo presente ${ }^{12}$.

Porém, o problema não se resolve de todo, quando encontramos versos que rejeitam ao ser, o nascimento e o fim. Estaríamos diante da eternidade e da infinidade do ser. O que é eterno e infinito, poderia ser compreendido como pertencente a um tempo indefinido (sem medida de início e fim, mas que transcorre numa continuidade incessante); ou pode significar a ausência absoluta do tempo, "intemporalidade" ou atemporalidade. Em qual sentido podemos situar o Ser de Parmênides? Na condição de um tempo que dura continuamente, o tempo perene, o tempo sem início e sem fim, mas no qual o Ser está agora e transcorre sendo sempre presente? Porém, isto nos remete à ideia de incompletude, pois se algo está sendo sempre, nunca se está plenamente concluído. Ou vamos entender o ser como totalmente fora do tempo; eterno e infinito porque não participa do tempo, esta condição de formação e deterioração a que as coisas mutáveis estariam sujeitas?

\section{Sobre o tempo em Platão}

De acordo com o Léxico de Platão, organizado por Schäfer, "os diálogos de Platão tematizam o tempo com frequência e de várias perspectivas" ${ }^{\text {"3 }}$. Tais perspectivas abrangeriam utilizações mais coloquiais sobre os diferentes processos que envolvem as questões humanas e da natureza ou para situar configurações míticas ou históricas. De fato, vários conceitos são encontrados nos textos dialógicos que nos remetem a algum significado do tempo. Inclusive nas divagações etimológicas do Crátilo, o nome Cronos (deus do tempo) é definido (396b, 401e) em associação aleatória à imagem da cabeça/inteligência e depois ao rio ou a água de Heráclito, como aquilo que passa de forma incessante.

\footnotetext{
${ }^{10}$ SPINELLI, Filósofos pré-socráticos, p. 306.

${ }^{11}$ KIRK; RAVEN; SCHOFIELD, Os filósofos pré-socráticos, pp. 259-6o.

${ }^{12}$ McKIRAHAN, A Filosofia antes de Sócrates, pp. 281-282.

${ }^{13}$ SCHÄFER, Léxico de Platão, p. 299.
} 
Para Puente, o tempo aparece ao longo dos diálogos ao menos em cinco sentidos: aión, kairós, exaíphnes, khrónos e nyn ${ }^{14}$. É provável que outros termos possam ser elencados com diferentes conotações do tempo. Puente enfatiza, a partir do autor francês Mattéi, que tais usos do tempo devem ser classificados como "figuras do tempo", e não como conceitos.

A despeito dos diferentes e possíveis usos sobre o tempo nos diálogos, Schäfer em seu Léxico ressalta que enquanto tratamento filosófico tal questão aparece de modo restrito, destacando-se, sobretudo, os diálogos Timeu, Parmênides e talvez algumas outras passagens.

Quanto ao Parmênides, foram apresentadas algumas considerações acima. Embora, como dissemos, a aplicação do conceito tempo possa ser associada nas passagens desse diálogo à dimensão matemática, enquanto unidade de medida entre um evento e outro; ou em sentido físico ou orgânico, na condição da mudança e degeneração das coisas do início ao fim; os debates ali travados podem nos remeter a reflexões sobre um conceito cosmológico ou mesmo metafísico e ontológico do tempo.

No Timeu, o tempo, enquanto investigação cosmológica, ganha relevância. Ali teríamos uma filosofia do tempo. O ordenamento cósmico efetuado pelo demiurgo implica também no ordenamento temporal, onde as formas do universo se manifestam e realizam seu existir. Assim como o mundo é uma imagem dos deuses eternos, o tempo é uma imagem da eternidade, ou, como dito no diálogo, isto que chamamos tempo, "é uma imagem móvel da eternidade" (37e, eikô kinêton tina aiônos). O tempo passa a ser apresentado no desdobramento deste diálogo, como passível das medidas que caracterizam o movimento a que os corpos do mundo estão sujeitos, como passado, presente, futuro - o que foi, o que é, o que será. Para tal movimento, ganha relevância a percepção do movimento celeste, as revoluções astronômicas no universo, o que, de fato, como sabemos, tornaram-se referências para as unidades cronológicas modernas, como o foram em muitas das sociedades antigas.

Parece-nos que enquanto conceito cosmológico, o tempo no Timeu oferece proximidade ao abordado no Parmênides. E neste caso, há uma concepção metafísica e ontológica que distingue a eternidade, enquanto um atributo da natureza do ser universal absoluto, da temporalidade a que estão submetidos os seres do mundo. O tempo enquanto “imagem móvel da eternidade", é uma realidade aparente, ilusória, um simulacro que imita de modo distante a realidade ontológica da eternidade que caracteriza o ser em sua identidade própria. O tempo que submete o cosmos e o que nele foi posto, representa a efemeridade em oposição à eternidade. $\mathrm{O}$ mundo efêmero não tem a durabilidade perene; o mundo sensível está sujeito ao tempo em oposição ao eterno e à eternidade, o que nos remeteria a uma realidade metafísica, pois "o tempo nasceu com o céu e junto a este, sob o modelo da substância eterna" (38c).

\section{Conclusão: temporalidade platônica - do tempo mítico ao tempo histórico}

Se tomarmos, como entendemos que deva ocorrer, uma leitura dos diálogos em seu conjunto e nas relações dialéticas e dialógicas que daí decorrem, não temos doutrinas ou teorias filosóficas fechadas nos textos platônicos. Assim, como noutros conteúdos, podemos perceber que a questão do tempo perpassa diferentes dimensões e permitem múltiplas análises e mantém o caráter aporético das temáticas.

Em relação ao tempo, percebemos que desde os usos linguísticos cotidianos já presentes no contexto em que foram produzidos os diálogos, encontramos conotações como

\footnotetext{
${ }^{14}$ Cf. PUENTE, Ensaios sobre o tempo na filosofia antiga, pp. 47-9. O autor não traduz todos esses termos, mas entendimentos possíveis seriam aion (a durabilidade da vida), kairós (o tempo oportuno), exaíphnes (o tempo súbito, o instante), Krónos (o deus do tempo), nyn (o agora).
} 
as indicadas que conceituam o tempo ora como unidade de medida, um elemento matemático; ora como movimento físico da natureza e dos seres sensíveis; ora, num sentido quase biológico, da geração, degeneração e morte/finitude dos seres; ora como unidade cosmológica e, numa forma mais elaborada, como conceito ontológico.

Entretanto, ocorre um movimento nos diálogos que nos permite ir além para extrair dali intensas abordagens de uma filosofia do tempo ou da temporalidade. Neste caso, arriscamo-nos a dizer que o movimento dialógico e dialético em Platão, no que tange ao conceito de tempo e temporalidade, nos permite verificar esta relação que vai de um tempo mítico, cíclico e simbólico como representado em cronos, que é desconstruído pela concepção de um tempo físico-material representado pela mudança natural da physis e das coisas, a um tempo ontológico e metafísico pensado na cosmologia, para avançar na direção da temporalidade histórica, marcada pelo transcurso dos seres, do mundo natural e humano, dos acontecimentos, inclusive na dimensão existencial e política em que se situam as ações e a vida na pólis em seu ethos, seu modo de existir.

Não pretendemos aqui - nos falta inclusive a competência para tal -, adentrar pela complexa narrativa dos mitos gregos e nem mesmo propomos uma abordagem em torno de uma "filosofia do mito", na expressão de Brisson ${ }^{15}$, embora seja tema de nossa curiosidade. Uma análise criteriosa exigiria, de nossa parte, a investigação comparativa entre as narrativas míticas que as mesmas receberam, inclusive na própria antiguidade grega, a partir das diferentes versões, em autores diferentes, o que agrava a dificuldade hermenêutica. No caso de Cronos, nos deparamos ainda com a dupla personificação que muitas vezes tem confundido as interpretações.

Numa versão, há o Titã Cronos, filho de Urano (o Céu) e Geia (ou Gaia, a Terra) contra quem se rebelou, a pedido da mãe, dado o totalitarismo urânico de não deixar nascer seus filhos, para que não lhe roubassem o poder. Foi exatamente o que ocorreu, quando Cronos castrou e derrotou a Urano, iniciando a segunda geração dos deuses titânicos. Cronos e a esposa/irmã Reia repetiram a saga de Urano, pois temendo o poder dos filhos contra si, Cronos devorava a todos ainda bebês, até que de modo semelhante à sua própria história com seu pai Urano, foi derrotado pelo filho Zeus, que conspirou contra Cronos, fazendo-o vomitar a todos os filhos devorados e, ao lado de Hera, iniciou Zeus a terceira geração dos deuses, e a primeira dos deuses olímpicos.

Ora, tal simbolismo - Cronos que devora aos filhos - tem sido interpretado como o deus que a todos devora, assim como o tempo que conduz à finitude dos seres, a velhice e a morte temporal, de onde não há escapatória, o que é uma imagem bastante pertinente e rica em desdobramentos.

No entanto, há também a representação de outra divindade - Chronos/kronos como um dos deuses olímpicos, cultuado sobretudo nos cultos órficos e que é identificado como o senhor do tempo, do princípio e do fim, embora em sua outra face seja Aion, a eternidade. Para alguns (Plutarco) Chronos/kronos, o deus órfico, seria a representação antropomórfica do Titã Cronos. Enfim, ambos, de algum modo, estão vinculados à imagem do tempo.

A filosofia antes de Sócrates promoveu a passagem das cosmogonias às cosmologias, das crenças míticas às interpretações da physis. Parece ser, no caso do tempo, um pouco do que ocorre com Parmênides, dentre outros e que o diálogo Parmênides em certo sentido nos permite observar, nas questões sobre o tempo e a temporalidade apontadas anteriormente.

No diálogo $O$ Político (268d - 273c), após o longo exercício lógico pelo método da divisão de gêneros, na tentativa de se chegar à definição de quem seja o político,

${ }^{15}$ BRISSON, Introdução à Filosofia do Mito. 
inicialmente este vem a ser definido como um "pastor de rebanhos", e a política, a técnica de "pastorear os homens" (267c). Porém, os personagens, o Estrangeiro e um outro Jovem Sócrates, concluem que esta definição do político como um "rei/pastor", numa imagem divinizada da função de governar, talvez se aplicasse noutra era, a era dos deuses, mas não seria mais válida para os tempos humanos vigentes. Ocorre então, no texto dialógico, a digressão mítica de Platão sobre Cronos, neste caso, a divindade titânica anterior ao tempo de Zeus.

A alegoria platônica nos coloca diante da sucessão temporal cíclica, uma espécie de eterno retorno, uma sucessão de épocas, onde no "tempo de Cronos", tudo transcorre na mais perfeita paz e harmonia, para o universo e para o mundo humano. Neste caso, o rei como "pastor" representa bem a imagem do político, a quem compete preservar a serenidade natural do rebanho humano que transcorre em tranquilidade, pois, o governo do universo, de fato, estaria na mão da divindade, um ciclo divino, da ordem universal. Porém, o tempo vivido, é o ciclo de Zeus; o tempo é humano, assim como seu governo e as mudanças daí decorrentes.

As duas eras representam a história cíclica e contínua do movimento circular do universo. Embora no tempo de Cronos tudo aparece ao contrário do que se presencia no tempo de Zeus; ou seja, o movimento dos astros se dá de oeste para leste e tudo nasce velho e morre jovem; é aí que impera a ordem e a perfeição, pois deus governa, cabendo ao reipastor apenas manter as coisas em dia, mas o comando é divino.

Já no tempo de Zeus, a divindade abandona os homens e a natureza à própria sorte; o movimento se inverte de leste para o oeste e tudo nasce jovem para depois envelhecer.

Ora, no primeiro caso, o tempo de Cronos, em que tudo nasce velho e rejuvenesce, há uma representação da esperança, da possibilidade de se evoluir do corruptível ao incorruptível, da necessidade à bonança, sob o comando divino. Já no tempo de Zeus, com o abandono divino, o movimento dos seres e da história humana é de declínio, de decadência. O tempo divino se converte no tempo natural, e este é o tempo negativo da degeneração. Como nos diz o Estrangeiro, no passo 269d:

Neste universo em que estamos, em certos momentos é o próprio Deus que guia a sua marcha e preside a sua revolução; noutros momentos deixa-o evoluir livremente, quando os períodos de tempo que lhe foram atribuídos terminaram, e o universo recomeça então por si mesmo, em sentido inverso, a sua trajectória circular, em virtude da vida que o anima e da inteligência com que foi favorecido, desde a origem, por aquele que o compôs ${ }^{16}$.

Assim, temos, neste mito platônico, o ciclo invertido de todas as coisas. Se no tempo de Cronos tudo vem da morte para a vida, da velhice para a juventude, do desordenado para o ordenamento, e a divindade, em seu governo, a tudo conduz para a harmonia perene, no tempo de Zeus, condenados à própria natureza, o mundo e os homens se veem na necessidade de encontrarem o melhor caminho para conduzirem o próprio destino, no interior desta temporalidade que avança do nascer ao morrer.

Esta alegoria platônica nos oferece uma visão cósmica do tempo que se diferencia da visão divina do mesmo; no tempo de Zeus, a natureza e os homens se guiam a si próprios, na lógica de sua própria temporalidade. Mais que isto, conforme sugere Droz, temos uma visão pessimista tanto do movimento cósmico quanto do humano, que avançam para a própria decadência, desgovernados, o que justifica a necessidade de se encontrar a melhor forma de

${ }^{16}$ DROZ, Os Mitos Platônicos, pp. 146-147. 
governo e a melhor definição para o político, de modo a amenizar esta situação de degeneração. Para Droz este mito platônico,

[...] para além das imagens cosmológicas ou antropológicas [...] abre talvez para uma 'filosofia da história', pessimista, é certo, visto que está dominada pela obsessão de um declínio inelutável, mas não trágica, pois o ciclo garante o reaparecimento do paraíso perdido ${ }^{17}$.

Neste caso, um paraíso reencontrado devido ao retorno cíclico - o de Cronos - onde tudo se reconstitui e se reorganiza novamente. Porém, enquanto no abandono da própria responsabilidade, à natureza e aos seres humanos, cabe encontrar o bom piloto político responsável não apenas por "pastorear" seu rebanho, já que não se está na calmaria, nem se é o "Rei Filósofo" de uma República ideal, mas sim um técnico habilidoso e virtuoso que consiga conter a decadência, fundamentado na razão capaz de elucidar; o único meio capaz de favorecer aquilo que o diálogo chama de política, como "a arte de tecer a cidade" em seus fios emaranhados. Para Droz, "pela virtude de uma razão eficaz ao serviço do governo [...] compete a tarefa de conter o progresso do mal e travar a decadência. Ao pessimismo da filosofia da história responde vitoriosamente a fé platônica na racionalidade ao serviço do bem"18.

Brisson enxerga neste mito do Político, "uma relação entre a cosmologia, a antropologia e a política" ${ }^{\text {. }}$. Em relação ao Timeu, há uma explicação cosmológica sobre o universo e seu movimento, carregada de significados astronômicos e simbólicos que fogem ao objetivo deste comentário. No entanto, o movimento de inversão temporal que ocorre entre um ciclo e outro no mito, entre a corrupção e a degeneração de tudo (tempo de Zeus) e a reconstituição plena do universo (tempo de Cronos), ainda que por uma era que vai e volta, o ser humano se vê sem alternativa que não seja aquela de encontrar uma saída política para sua situação de abandono e desgoverno.

Na dialética dos diálogos, a referência ao "reino de Cronos" retorna em As Leis (711c 714b) em torno do debate sobre qual seria a melhor forma para a constituição da cidade - se monarquia, democracia, oligarquia etc., caminhando para a ideia de que nem uma dessas formas representa o modelo ideal, já que se corrompem, e talvez o melhor seja a mistura das constituições (o misto governo), de tal maneira que se aproxime do tempo em que reinava ou reinará Cronos, onde prevalece o que é bom e justo (As Leis 713c-e); enquanto isto, cabe estabelecer um governo amparado pelas leis e pelos legisladores, educados pela razão, capazes de preservar a boa administração da cidade humana (As Leis 714a). Neste sentido, ainda que mesclando o mítico, o histórico e o racional, a investigação sobre o nascimento e a origem das cidades e de suas constituições e formas de governo, promovida no livro III de As Leis $(676 a-684 a)$, nos revela indícios claros de uma concepção de tempo que se aproxima da temporalidade histórica. Ao menos neste intervalo cíclico dos deuses, cabe ao ser humano assumir o poder diretivo e político, como será proposto no diálogo As Leis, no esforço racional e histórico de conduzir a história da cidade por meio da política.

Uma temporalidade histórica que, a nosso ver, nos remete a uma percepção filosófica da história e da historicidade das cidades e dos seres humanos; porém, para ficar apenas no trocadilho, isto é uma outra história, a ser desenvolvida noutro momento.

\footnotetext{
${ }^{17}$ DROZ, Os Mitos Platônicos, p. 156.

${ }^{18}$ DROZ, Os Mitos Platônicos, p. 161.

${ }^{19}$ BRISSON, Leituras de Platão, p. 220.
} 


\section{Referências}

ABBAGNANO, Nicola. Dicionário de Filosofia. São Paulo: Martins Fontes, 2000.

BENOIT, Hector. Platão e as temporalidades: a questão metodológica. São Paulo: Annablume, 2015.

BENOIT, Hector. A Odisseia de Platão: as aventuras e desventuras da dialética. São Paulo: Annablume, 2017.

BRISSON, Luc. Introdução à Filosofia do Mito. São Paulo: Paulus, 2014.

BRISSON, Luc. Leituras de Platão. Porto Alegre: Edipucrs, 2003.

DROZ, Geneviève. Os Mitos Platônicos. Mira-Sintra: Publicações Europa-América, 1992.

GRIMAL, Pierre. Mitologia grega. Porto Alegre: L\&PM, 2010.

IGLÉSIAS, M. \& RODRIGUES. F. Platão. Parmênides. Rio de Janeiro/São Paulo: PUC/Loyola, 2003.

KIRK, G. S.; RAVEN, J. E.; SCHOFIELD, M. Os filósofos pré-socráticos. 4 ed. Trad. C. A. L. Fonseca. Lisboa: Fundação Calouste Gulbenkian, 1994.

McKIRAHAN, Richard. A Filosofia antes de Sócrates - Uma introdução com textos e comentários. Trad. E. W. Pereira. São Paulo: Paulus, 2013.

PEREIRA FILHO, Gérson. Uma filosofia da história em Platão - o percurso histórico da cidade platônica de As Leis. São Paulo: Paulus, 2009.

PRADEAU, Jean-François. Les Mythes de Platon. Paris: GFlammaion, 2004.

PUENTE, Fernando Reys. Ensaios sobre o tempo na filosofia antiga. São Paulo: Annablume, 2010.

SANTOS, José Trindade. Parmênides, Da Natureza. Brasília: Thesaurus, 2000.

SCHÄFER, Christian (Org.). Léxico de Platão. São Paulo: Loyola, 2012.

SPINELLI, Miguel. Filósofos pré-socráticos - Primeiros mestres da filosofia e da ciência grega. Porto Alegre: Edipucrs, 1998. 